\title{
MAŁGORZATA GEOWACKA-HELAK
}

Uniwersytet im. Adama Mickiewicza w Poznaniu,

Biblioteka Uniwersytecka

\section{Profesor Aleksander Birkenmajer jako dyrektor Biblioteki Uniwersyteckiej w Poznaniu w latach 1939-1947}

\begin{abstract}
Streszczenie. Artykuł przedstawia profesora Aleksandra Birkenmajera, przedwojennego dyrektora Biblioteki Uniwersyteckiej w Poznaniu. Okazją do jego przypomnienia jest przypadająca w 2017 roku 50. rocznica śmierci. Kierownictwo Biblioteki Uniwersyteckiej rozpoczął w marcu 1939 roku, tuż przed wybuchem II wojny światowej. Podczas okupacji na kilka lat rozstał się ze współpracownikami. Do Biblioteki Uniwersyteckiej w Poznaniu powrócił w marcu 1945 roku, aby uczestniczyć w niezwykle trudnej odbudowie życia bibliotecznego w latach 1945-1947. Do napisania artykułu zostały wykorzystane materiały archiwalne zachowane w Archiwum Biblioteki Uniwersyteckiej w Poznaniu.
\end{abstract}

Słowa kluczowe: Aleksander Birkenmajer, Biblioteka Uniwersytecka w Poznaniu.

W niniejszym szkicu pragnę przedstawić działalność profesora Aleksandra Birkenmajera jako dyrektora Biblioteki Uniwersyteckiej w Poznaniu. Okoliczności historyczne sprawiły, że jego kadencja (1939-1947) była niezwykła, najpierw przerwał ją wybuch wojny (wrzesień 1939), później (1945-1947) w drastycznie odmienionych realiach społeczno-politycznych musiał zająć się odbudową życia bibliotecznego i wymagającym niezwykłej energii i pomysłowości procesem przejmowania i zabezpieczania różnego rodzaju księgozbiorów opuszczonych i przejmowanych przez nowe władze ${ }^{1}$.

1 Bardzo obszernie działalność profesora w tym zakresie przedstawił Ryszard Nowicki, dlatego ten obszar działalności profesora pominę w dalszym ciągu swoich rozważań. Zob. R. Nowicki, Działalność Aleksandra Birkenmajera na rzecz ochrony zbiorów bibliotecznych, Poznań 2006. 


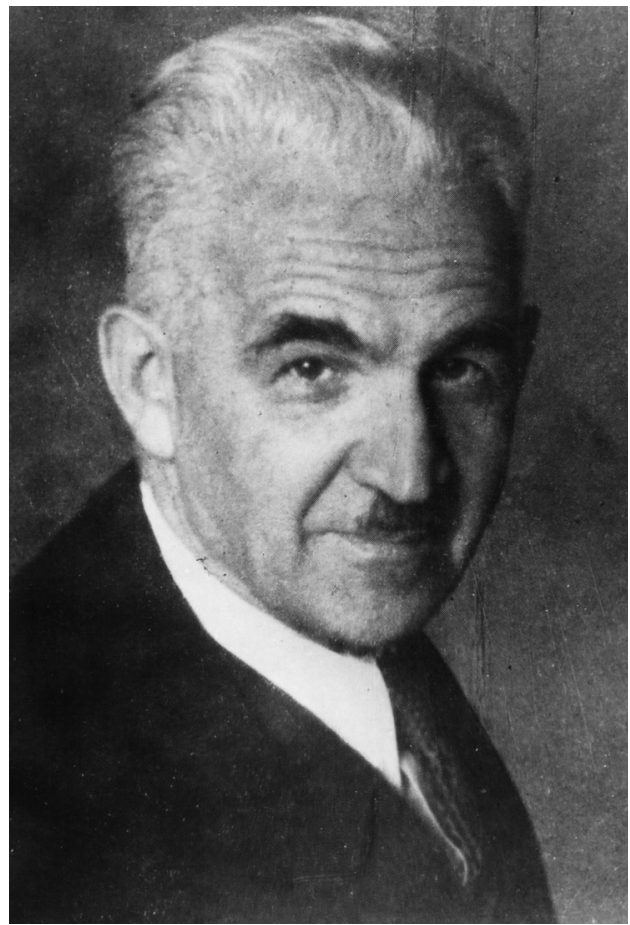

Krótko przypomnę okoliczności powołania Aleksandra Birkenmajera na stanowisko dyrektora Biblioteki Uniwersyteckiej w Poznaniu. Stosowne informacje przynoszą dokumenty zachowane $\mathrm{w}$ archiwum naszej Biblioteki.

W roku 1937 dotychczasowy dyrektor dr Stefan Vrtel-Wierczyński został powołany na stanowisko dyrektora Biblioteki Narodowej w Warszawie. Ówczesne władze uniwersyteckie bardzo wysoko oceniły jego dotychczasową pracę:

Biblioteka Uniwersytecka traci swego dyrektora prof. Stefana Wierczyńskiego, który otrzymał zaszczytną nominację na dyrektora Biblioteki Narodowej w Warszawie. Objąwszy przed 10 laty stanowisko dyrektora Biblioteki Uniwersyteckiej w Poznaniu włożył prof. Wierczyński ogromną ilość trudu i poświęcenia w swoją pracę, to też z żalem żegnamy go tracąc w nim doskonałego organizatora, a przy tym wybitnego uczonego².

Bardzo szybko, bo już 14 lipca tego samego roku ogłoszono konkurs na stanowisko dyrektora, starannie określając warunki, jakie ewentualny kandydat musi spełniać: doktorat, dłuższa praktyka w większej bibliotece naukowej, prace naukowe, przede wszystkim z zakresu bibliologii (bibliografii, bibliotekoznawstwa), ogólna znajomość realiów w bibliotekarstwie polskim i światowym. Podania ze stosowną dokumentacją miały wpływać do władz uczelni do 16 sierpnia 1937 roku.

W odpowiedzi otrzymano oferty doktorów: Józefa Grycza z Warszawy, Andrzeja Wojtkowskiego z Poznania, Karola Buczka z Krakowa, Franciszka Smolki ze Lwowa, Aleksandra Birkenmajera z Krakowa i Eustachego Gaberlego ze Lwowa ${ }^{3}$.

Były to bardzo poważne kandydatury, każdy z tych kandydatów legitymował się sporym dorobkiem i poważnym doświadczeniem $\mathrm{w}$ pracy

2 Kronika Uniwersytetu Poznańskiego za rok szkolny 1936/37, Poznań 1938, s. 10.

3 Archiwum BU, Komisja Biblioteczna 1934-1938, sygn. 23, s. 39. 
bibliotecznej. A mimo to, z przyczyn, których nie potrafię na podstawie dostępnej dokumentacji określić, konkursu nie rozstrzygnięto. Do roku 1939 obowiązki dyrektora pełnili kolejno: dr Stefan Wierczyński, którego ostatecznie pożegnano w październiku 1937 roku $^{4}$, dr Bożena Szulc-Golska, prof. dr Jan Józef Bossowski ${ }^{5}$.

Wreszcie z początkiem marca 1939 roku funkcję tę powierzono prof. Aleksandrowi Birkenmajerowi, który najlepiej spełniał wszelkie warunki określone przez władze Uniwersytetu Poznańskiego.

Jego sylwetkę najpełniej przedstawił Stefan Vrtel-Wierczyński, rekomendując go w 1929 roku na stanowisko dyrektora Biblioteki Uniwersyteckiej w Warszawie:

P. dr Birkenmajer należy do najwybitniejszych naszych bibliotekarzy. Posiada dokładną znajomość bibljotekarstwa, zarówno praktyczną, jak teoretyczną. Zwiedził liczne biblioteki zagraniczne, ma więc szeroki pogląd na sprawy organizacyjne, techniczno-bibljotekarskie. W Bibliotece Jagiellońskiej kieruje oddziałem rękopisów i starych druków, wymagającym gruntownej wiedzy i specjalnych wiadomości z dziedziny księgoznawstwa. Dorobkiem jego jest poważny poczet prac naukowych, wydanych osobno, lub ogłoszonych w czasopismach. Dr Birkenmajer, jako fachowiec bibljotekarz i jako człowiek, jest w zupełności przygotowany do objęcia kierowniczego stanowiska w bibljotekarstwie ${ }^{6}$.

Ten krótki, kilkumiesięczny okres między marcem a wrześniem 1939 roku wypełniała prof. Birkenmajerowi, rzec można, rutynowa aktywność niejako automatycznie przypisana do stanowiska, które właśnie objął. Poświadczają to podpisywane przez niego okólniki i szczegółowe zarządzenia: letnie urlopy pracowników ${ }^{7}$, praktyk bibliotecznych, zmian godzin otwarcia czytelni i wypożyczalni.

28 kwietnia 1939 roku dyrektor wizytował Bibliotekę Poznańskiego Towarzystwa Przyjaciół Nauk, zapoznał się szczegółowo z jej organizacją i zbiorami ${ }^{8}$. Biblioteka ta była administracyjnie podporządkowana Bibliotece Uniwersyteckiej i w tym czasie kierował nią mgr Jan Baumgart.

4 Sprawozdanie Biblioteki Uniwersyteckiej w Poznaniu za rok akademicki 1937/38, sygn. 113, s. 5.

5 Archiwum BU, teczka Organizacja i administracja wewnętrzna 1937-1938, sygn. 91, s. 5-6.

6 Archiwum BU, teczka Sprawy personalne 1 II 1927-25 X 1937 r., sygn. 2a.

7 Archiwum BU, teczka Zarządzenia wewnętrzne 1938-1939, sygn. 88, s. 49.

8 Archiwum BU, teczka Biblioteka Towarzystwa Przyjaciół Nauk w Poznaniu 1 IX 1934-VI 1939 r., sygn. 250, s. 241. 
Od 8 maja do 30 czerwca prof. Birkenmajer korzystał z urlopu zdrowotnego. Na czas swojej nieobecności stosownym pismem precyzyjnie określił zasady funkcjonowania Biblioteki:

1. Zastępować mnie będzie P. dr Szulc-Golska. W razie jej nieobecności (urlop wakacyjny itp.) zastępstwo sprawować będzie dr Kawecka, dr Posadzy lub mgr Baumgart, stosowanie do swego starszeństwa służbowego. P. dr Szulc-Golska otrzymuje duplikat klucza od mojego biurka, przez co będzie miała również dostęp do wszystkich innych kluczy bibliotecznych. O ileby dr Szulc-Golska wyjeżdżała na dłuższy czas z Poznania wspomniany duplikat zostanie złożony w Sekretariacie.

2. Na czas mojej nieobecności stały mój adres będzie następujący: Kraków, ul. Siemiradzkiego 19, m. 5. O ile zajdzie potrzeba, podam z Krakowa inny adres.

3. Listy prywatne do mnie adresowane prosze przeadresować do Krakowa jw. Pobory moje płatne na 1.VI.1939 r. proszę również przesłać pod powyższym adresem, ale na nazwisko: A. Birkemajerowa, ażeby nie stwarzać trudności w podjęciu ich przez moją żonę. Podobnie proszę postąpić z poborami moimi płatnymi na 1.VII.1939 r., o ile tymczasem nie podam innych wskazówek9.

Jak wynika z powyższego pisma, rodzina prof. Birkenmajera nie przeprowadziła się jeszcze do Poznania.

Wszystkie pozostałe wydane przez niego zarządzenia nie wykraczają poza codzienną rutynę funkcjonowania placówki tego typu: przesunięcia personalne $\mathrm{w}$ okresie urlopowym, szczegółowe regulacje dotyczące zasad wypożyczania książek z księgozbiorów podręcznych, zasad funkcjonowania poszczególnych agend bibliotecznych w okresie wakacyjnym, wnioski awansowe, wnioski o odznaczenia dla wybranych pracowników, przeprowadzenie skontrum itp.

Warto zwrócić uwagę na ostatnie podpisane przez dyrektora urzędowe pismo datowane 1 września 1939 roku, a skierowane do Ministerstwa Wyznań Religijnych i Oświecenia Publicznego, w którym prosi o pozostawienie dra Ludwika Posadzego w służbie czynnej:

[...] stan zdrowia dra Posadzego jest zupełnie dobry i zgoła nie stanowi przeszkody w dalszej pracy, a specjalne wykształcenie w pewnych dziedzinach wiedzy (zwłaszcza w filozofii ścisłej i pedagogiki) jest dla Biblioteki nader cenne. Należy także wziąć pod uwagę, że szczupła ilość bibliotekarzy naukowych, jaka

9 Archiwum BU, teczka Osobowe ogólne 1 IX 1934-7 IX 1939 r., sygn. 3, s. 153. 
jest zatrudniona w tutejszej Bibliotece, może wskutek obecnej sytuacji politycznej zostać jeszcze zredukowana. Ubytek dra Posadzego byłby w tych warunkach w wysokim stopniu niekorzystny dla Biblioteki. Dyrekcja nadmienia jeszcze, że dr Posadzy pracował bardzo intensywnie na polu oświaty narodowej podczas zaboru niemieckiego. W ostatnim czasie otrzymał od Polskiej Akademii Umiejętności nagrodę im. Ks Adama Jakubowskiego za pracę p. tyt. Poglądy pedagogiczne Adama Mickiewicza. Obecnie jest w trakcie habilitowania się na podstawie wyżej wymienionej pracy ${ }^{10}$.

W piśmie ważna jest nie tylko przebijająca zeń troska o pracownika, ale też data i wynikająca z niej pewność, że niezależnie od dziejowych burz trzeba do końca wypełniać swoje obowiązki.

Niewiele można powiedzieć o życiu Biblioteki w pierwszych dniach wojny, nie zachowały się żadne dokumenty. Spisane znacznie później przez Jana Baumgarta Sprawozdanie z lat 1939-1945 rozpoczyna się od dnia 13 września, to jest od momentu pojawienia się w Bibliotece Niemców. Ze wspomnień Zofii Kaweckiej, która w tym czasie pełniła funkcję komendanta gmachu wynika, że profesor wcześniej wyjechał z Poznania, żegnając się z nią słowami: „pod Pani opieką zostawiam Bibliotekę"11.

Jeszcze we wrześniu 1939 roku wszystkie biblioteki znajdujące się w obrębie granic tzw. Wartheland zostały zajęte i opieczętowane przez Gestapo. Kilka miesięcy później, 13 grudnia 1939 roku, namiestnik Greiser wydał zarządzenie, na mocy którego należało zgłaszać na specjalnych formularzach księgozbiory i biblioteki własności publicznej i prywatnej nieniemieckiej. W praktyce oznaczało to ich konfiskatę, w ramach tej akcji przepadł m.in. bogaty księgozbiór prof. Birkenmajera.

Wojna boleśnie doświadczyła prof. Birkenmajera, który przeszedł więzienie w Krakowie, Wrocławiu, obóz koncentracyjny w Oranienburgu od 6 listopada 1939 do 24 października 1940 roku. Równie dramatyczne były losy przedwojennego personelu Biblioteki Uniwersyteckiej: osiem osób straciło życie (m.in. Ludwik Posadzy, więzień Fortu VII, i Józef Kampera, który poległ w powstaniu warszawskim), dziesięcioro innych zostało wysiedlonych.

W Poznaniu trwały jeszcze walki o Cytadelę, kiedy prof. Birkenmajer napisał z Krakowa (21 lutego 1945 roku) list do Haliny Alkiewicz, jako osoby mieszkającej blisko Biblioteki Uniwersyteckiej:

Donoszę, że wraz z p. kol. Baumgartem i woźnym A. Kasprzakiem jesteśmy od dwu tygodni przygotowani do wyjazdu stąd do Poznania - ponieważ jednak

\footnotetext{
10 Archiwum BU, Akta osobowe Ludwika Posadzego, sygn. 225.

11 Rękopis BU, Zofia Kawecka, Pamiętnik z 1. 1939-1945, sygn. 3544.
} 
(według komunikatów bojowych) walki w Poznaniu jeszcze trwają (wzgl. trwały do ostatnich dni), przeto wyjazd nasz uległ na razie odroczeniu. W każdym razie mam nadzieję najpóźniej koło 1.III. dotrzeć do Poznania. Z polecenia P. Ministra Oświaty zostałem zaliczony do pięcioosobowej ekipy, która ma za zadanie zabezpieczyć nieruchomy i ruchomy majątek Uniwersytetu Poznańskiego, oprócz mnie wchodzą do tej ekipy profesorowie Suszko, Witkowski, Kapuściński i Górski (z Akademii Handlowej). P. Baumgart przyjedzie albo równocześnie ze mną albo przyjedzie po mnie ${ }^{12}$.

W związku z powierzonym zadaniem zabezpieczenia księgozbiorów bibliotecznych prywatnych i publicznych prof. Birkenmajer poprosił o utworzenie zespołu złożonego z dawnych pracowników Biblioteki Uniwersyteckiej, Biblioteki Raczyńskich i Biblioteki Archidiecezjalnej. Kierownictwo tego zespołu powierzył Halinie Alkiewicz. Prywatnie poprosił o zapewnienie noclegu:

[...] najuprzejmiej proszę o obmyślenie dla mnie, i ewentualnie dla czterech moich kolegów (pp. Suszko, Witkowski, Kapuściński i Górski), jakiegoś - choćby najskromniejszego - miejsca noclegowego. Jesteśmy przygotowani na wszelkie niewygody, chodzi jednak o dach nad głową. Co do mnie, wystarczy mi w zupełności jakiś kąt w suterenach Biblioteki Uniwersyteckiej, o ile tam zastanę łóżko z najniezbędniejszą pościela, stół i dwa krzesła.

Ostatecznie do Poznania Birkenmajer dotarł w marcu 1945 roku. Tak odnotowała to w kronice Biblioteki Uniwersyteckiej Maria Michałowska: „19.III. właściwe kierownictwo Biblioteki przejął od dr Plucińskiego tymczasowego kierownika Biblioteki prof. Aleksander Birkenmajer, przedwojenny dyrektor Biblioteki Uniwersyteckiej w Poznaniu, który wrócił z wysiedlenia"13. Powrót na stanowisko dyrektora oznaczał wyraźnie zwiększony zakres obowiązków: umożliwienie korzystania ze zbiorów przez czytelników oraz ochronę księgozbiorów opuszczonych, porzuconych i przejmowanych przez nowe władze.

Początkowo, od 14 lutego do 18 marca 1945 roku Biblioteka nie posiadała żadnych funduszy. Zgłaszające się osoby pracowały bezpłatnie. Pierwsze fundusze przywiózł z Krakowa dopiero prof. Birkenmajer. Był to zasiłek w wysokości 15 tys. zł otrzymany za pośrednictwem Związku Bibliotekarzy Polskich w Krakowie, przeznaczony na akcję ratowania

12 Archiwum BU, Korespondencja. Protokóły zdawczo-odbiorcze 1945-1947, sygn. 543 , s. 1 .

${ }^{13}$ Kronika Biblioteki Uniwersyteckiej w Poznaniu, sygn. 357 
księgozbiorów porzuconych ${ }^{14}$. Pierwsza dotacja rządowa na potrzeby naukowe wpłynęła pod koniec czerwca 1945 roku. W miarę normowania się stosunków część pracowników otrzymywała wynagrodzenie z etatów, jakimi dysponował uniwersytet. W roku 1946 wszyscy pracownicy Biblioteki otrzymywali wynagrodzenie służbowe z funduszy budżetowych Uniwersytetu Poznańskiego ${ }^{15}$.

Po powrocie prof. Birkenmajer zamierzał skompletować zespół przedwojennych pracowników zatrudnionych w Bibliotece. Zachował się w naszym archiwum jego list z 22 marca 1945 roku do Zofii Kaweckiej, która przebywała w Sandomierzu:

Donoszę, że w dniu 18 b.m. powróciłem do Poznania i dniem następnym objąłem z powrotem kierownictwo Biblioteki Uniwersyteckiej. Wobec licznych i ważnych zadań, jakie są tu do spełnienia, pragnę w jak najkrótszym czasie skompletować (o ile możności) przedwojenny personel Biblioteki. Na razie z tego personelu pracują już, oprócz mnie, następujące osoby: mgr Jan Baumgart, p. Aniela Koehlerówna, p. Halina Alkiewicz, p. Jan Spychalski i p. Maria Kramperowa oraz dwu funkcjonariuszy niższych. Byłbym bardzo rad, jeśliby okoliczności pozwoliły Pani niebawem powiększyć swą osobą to szczupłe grono fachowe ${ }^{16}$.

Pierwszy okólnik nr 1 pro $1945^{17}$ właśnie personelowi został poświęcony. Warto go przytoczyć:

Grono pracowników wszelkiego rodzaju, zatrudnionych $\mathrm{w}$ podległej mi Bibliotece, wynosi w dniu dzisiejszym 35 osób (w tym 16 mężczyzn, a 19 kobiet) i rozpada się na dwie grupy w stosunku jak 10:25. Pierwszą tworzą osoby, które w dniu 1.IX.1939 r. wchodziły w skład personelu Biblioteki, drugą te osoby, które ochotniczo zgłosiły się do pracy w lutym i marcu br. Prawny stosunek tych osób do Biblioteki wzgl. do Uniwersytetu jest jeszcze zgoła nieustalony; wyjaśnienia, jakie otrzymałem w Sekretarjacie Uniwersytetu, opiewaja, że Uniwersytet traktuje na razie pracę tych osób jako przejściową i czysto ochotniczą w żadnym kierunku nie przesądzając możliwości dalszego zatrudnienia ich (w tej czy innej formie) przy Bibliotece. Stan taki nie jest korzystny ani dla zainteresowanych, ani dla Biblioteki. Pragnąc mu położyć kres, chcę jeszcze w tym miesiącu lub

${ }^{14}$ M. Głowacka-Helak, Rewindykacja księgozbioru Biblioteki Uniwersyteckiej w Poznaniu oraz zabezpieczanie zbiorów porzuconych i opuszczonych w latach 1945-1946, „Roczniki Biblioteczne" 1991, z. 1/2, s. 279.

15 Archiwum BU, Sprawozdanie roczne 1945-1946, sygn. 349, s. 128.

${ }^{16}$ Archiwum BU, Akta osobowe dr Zofii Kaweckiej, sygn. 295, s. 109.

17 Archiwum BU, Okólniki 30 V 1945-17 XII 1946, sygn. 296, s. 42. 
najdalej w pierwszym tygodniu kwietnia wystapić $\mathrm{z}$ wnioskiem o to, żeby te osoby, które mają zamiar nadal pracować w Bibliotece, zostały do niej przyjęte umownie (kontraktowo); przewiduję dla nich pobory służbowe w ramach od IX do VIII grupy uposażenia (tj. od 455 do 650 zł miesięcznie dla samotnych) oraz przepisane przez ustawę dwutygodniowe wypowiedzenie.

Sformułowanie ostatecznych wniosków poprzedził w dniach 27-29 marca osobistą rozmową z wszystkimi pracownikami.

Zatrudnionych w Bibliotece na dzień 1 września 1945 roku było 75 osób i choć w porównaniu ze stanem z 1939 (45 osób) oznaczało to znaczące powiększenie, była to wobec ogromu czekających zadań liczba niewystarczająca.

Okólnikiem nr 2 pro 1945 prof. Birkenmajer wprowadził tymczasowy schemat organizacyjny Biblioteki oraz rozdzielił obowiązki między poszczególnych pracowników. Wyglądało to następująco:

- kierownik: prof. Birkenmajer, jego zastępca mgr Baumgart,

- sekretariat: p. Kamperowa,

- referat remontu i porządkowania gmachu: dr Pluciński,

- udostępnianie zbiorów: p. Spychalski,

- zabezpieczanie i segregacja księgozbiorów zagrożonych zniszczeniem: mgr Rudkowska i p. Koehlerówna,

- magazyn: p. Pankowski.

Osoby pracujące w Bibliotece ochotniczo miały otrzymać przydział pracy w toku akcji przewidzianej w okólniku nr 1 pro 1945.

Schemat ten okazał się bardzo efektywny, bo już 26 marca Biblioteka Uniwersytecka mogła udostępnić swoje zbiory pracownikom naukowym uczelni, początkowo tylko w godzinach 8-15, bowiem, uwzględniając trudne warunki materialne życia, prof. Birkenmajer ustalił dla pracowników Biblioteki obowiązkowy czas pracy na 5 godzin dziennie; dwa miesiące później, gdy warunki bytowania wyraźnie się poprawiły, rozporządzeniem z dnia 8 maja przywrócił sześciogodzinny dzień pracy.

Pośród nowo zatrudnionych pracowników fachowi, doświadczeni bibliotekarze stanowili niewielki procent, większość miała co prawda wiele zapału, ale niewiele wiedzy i doświadczenia. Z myślą o nich dyrektor zorganizował czterotygodniowy kurs bibliotekarski. Zadanie to powierzył Janowi Baumgartowi, który w cyklu 23-godzinnych wykładów zapoznał nowych pracowników z podstawowymi zasadami pracy w Bibliotece.

Prof. Birkenmajer zdawał sobie sprawę, że jest to rozwiązanie doraźne, że wobec czekających zadań Biblioteka będzie potrzebować gruntownie wykształconych pracowników. Dlatego już w początku września 
1945 roku skierował do Ministerstwa Oświaty Wydziału Bibliotek list, w którym informował o zamiarze zorganizowania półrocznego kursu, który objąć miał nowo przyjętych pracowników oraz (w miarę możności) innych kandydatów na bibliotekarzy. Wedle tego projektu kurs trwał od 1 października 1945 do 13 kwietnia 1946 roku, a wykładowcami byli pracownicy Biblioteki: dr Bożena Szulc-Golska, dr Zofia Kawecka, mgr Jan Baumgart i mgr Witalis Ludwiczak ${ }^{18}$. Dla siebie Birkenmajer wyznaczył wykłady z zakresu zbiorów specjalnych, księgoznawstwa oraz nauki o bibliotekach. Szkolenie to - na podstawie decyzji dyrektora - było obowiązkowe dla wszystkich nowo przyjętych pracowników i tych, którzy co prawda zaczęli pracę jeszcze przed wojna, ale nie zdążyli zdać egzaminu bibliotekarskiego. Ostatecznie na kurs zgłosiły się 54 osoby, w tym 36 spośród pracowników Biblioteki Uniwersyteckiej. Ministerstwo wsparło tę inicjatywę Birkenmajera dotacją w wysokości 45 tys. zł.

W okólniku nr 8 z 18 czerwca 1945 roku $^{19}$, wydanym po trzech miesiącach od powrotu do Poznania, prof. Birkenmajer tak napisał:

Dziś mijają trzy miesiące od dnia 18 marca br., w którym powróciłem do Poznania i po 51 /2-letniej przerwie ponownie objąłem kierownictwo Biblioteki Uniwersyteckiej. Gmach jej zastałem poważnie uszkodzony i w $80 \%$ pozbawiony szyb; pustki w kasie Biblioteki, brak jakiejkolwiek namiastki budżetu, nieliczny zespół przedwojennych pracowników, zadania ogromne i niecierpiące zwłoki tym bardziej, że oprócz kierownictwa samej Biblioteki nałożono na mnie obowiązek zabezpieczania i segregacji księgozbiorów "opuszczonych i porzuconych" na terenie dwu województw; w tym zaś względzie kompetencje moje niejasno określone, krzyżują się z kompetencjami lub samowolą innych czynników.

Jednocześnie tak oceniał własną działalność:

Nie wszystkie moje plany i zamierzenia dały się już urzeczywistnić; przeciwnie, robiąc dziś obrachunek z ubiegłych trzech miesięcy, dochodzę do wniosku, że większość zadań, jakie przed sobą widziałem, nie została jeszcze rozwiązana. Tym niemniej zamykam z dniem dzisiejszym pierwszy okres mojej działalności, działalności po większej części dorywczej, z daleka tylko przypominającą systematyczność, która winna cechować bibliotekarza i jego pracę.

Za sukces uznał uruchomienie (w skromnym zakresie) Czytelni Ogólnej oraz rozpoczęcie kursu bibliotekarskiego.

${ }^{18}$ Archiwum BU, Kurs bibliotekarski 1945-1949, sygn. 439, s. 32.

19 Archiwum BU, Okólniki 30 V 1945-17 XII 1946, sygn. 296, s. 62. 
W tym samym piśmie nakreślił ogólne ramy wewnętrznej organizacji Biblioteki Uniwersyteckiej w Poznaniu:

Przed wojną wewnętrzna organizacja naszej Biblioteki opierała się na okólniku nr 10 pro 1936/7, wydanym przez ówczesnego dyrektora, prof. dr Stefana Wierczyńskiego w dniu 9.X.1936 r. Do tego okólnika mam teraz nawiązać, uwzględniając jednak bardzo istotne różnice, jakie zachodzą pomiędzy położeniem Biblioteki w r. 1936 a w r. 1945. Wypływają one z trzech głównych źródeł: po pierwsze Biblioteka, jako taka nie idzie jeszcze "pełną parą", tak co do agend jak co do wykwalifikowanego personelu; po drugie stan gmachu wymaga utworzenia osobnych referatów remontu i uporządkowania budynku i zbiorów; po trzecie w życie Biblioteki wtargnął nowy element: obowiązek ratowania książek i księgozbiorów na dużej połaci kraju. Na skutek tych przyczyn schemat przedwojenny jest $\mathrm{z}$ jednej strony za szeroki, a z drugiej za wąski; należy go więc przystosować do obecnej sytuacji, biorąc przytem pod uwagę, że ta sytuacja jest jeszcze płynna, bo podlega i nadal podlegać będzie ewolucji (przewidywane dalsze powiększenie personelu i rozszerzenie agend ściśle bibliotecznych).

Poważnym problemem dla dyrektora był fizyczny stan gmachu Biblioteki. W czasie walk o Poznań w lutym 1945 roku budynek został poważnie uszkodzony trzema pociskami artyleryjskimi, z których jeden trafił w dach, a dwa inne we frontową ścianę budynku. Okna Biblioteki oraz dach szklany nad główną klatką schodową utraciły ok. 80\% szyb. Instalacje centralnego ogrzewania oraz inne przewody wodne w wielu miejscach popękały na skutek mrozów. Na szczęście księgozbiór i katalogi zachowały się w zupełnym porządku. Już w liście do Senatu z dnia 9 kwietnia Birkenmajer pisał:

Pozwalam sobie wznowić sprawę budowy nowego gmachu dla podległej mi Biblioteki, która to sprawa była przedmiotem wstępnych studiów, jeszcze w roku 1938 i 1939, kiedy p.o. kierownikiem Biblioteki był prof. J.J. Bossowski, a obecnie musi być uważana za niezwykle pilną z czterech zwłaszcza powodów ${ }^{20}$.

W tym miejscu wskazał na pomnożenie zasobów Biblioteki podczas okupacji. Było ono na tyle znaczące, że jeszcze ówczesny dyrektor dr Lattermann został zmuszony niektóre $\mathrm{z}$ dawniej skatalogowanych książek usunąć z magazynów i przenieść m.in. do kościoła św. Stanisława na Winiarach, żeby zyskać przestrzeń na nowe nabytki. Birkenmajer też, całkiem

${ }^{20}$ Archiwum BU, teczka Sprawy gmachu Biblioteki Uniwersyteckiej 1945-1947, sygn. 467 , s. 1 . 
zasadnie, spodziewał się w najbliższym czasie gwałtownego wzrostu zasobów Biblioteki dzięki przejęciu książek pochodzących ze zbiorów konfiskowanych przez byłe władze niemieckie i tych powojennych, których zabezpieczaniem sam się z wielkim powodzeniem zajmował.

Wojenne zniszczenia Poznania - zdaniem Birkenmajera - stworzyły nowe możliwości wyboru stosowniejszego miejsca do budowy nowej biblioteki. Powołał się na dokończony podczas wojny nowy gmach Biblioteki Jagiellońskiej w Krakowie projektowany przez prof. Wacława Krzyżanowskiego, znakomitego znawcę budownictwa bibliotecznego. Dlatego proponował, by Senat powołał do życia osobną komisję, która przygotowywałaby wnioski w sprawie budowy nowego gmachu Biblioteki.

W liście z 23 sierpnia 1945 roku do Zarządu Miejskiego m.stoł. Poznania Wydziału Techniczno-Budowlanego zwrócił się w sprawie uwzględnienia wzniesienia owego gmachu dla Biblioteki Uniwersyteckiej w planach rozbudowy. Miejsce dla niego widział w dzielnicy Jeżyce. Ogród Zoologiczny stanowił według niego idealny teren pod nowoczesną, dużą bibliotekę. Jak zauważył, już przed wojną zwierzyniec miał być usunięty z tego ogrodu i przeniesiony na przedmieście Golęcin.

Propozycja ta spotkała się chyba z przychylnością władz uczelni, gdyż rektor $\mathrm{w}$ piśmie z 22 października upoważnił dyrektora, by wraz z wyznaczonym przez niego prorektorem rozpoczął pertraktacje z władzami miasta o przyznanie uczelni wskazanych terenów, w zamian oferował miastu dotychczasowy gmach Biblioteki Uniwersyteckiej.

Rektor UP w piśmie z 22 października 1945 roku zawiadomił dyrektora Biblioteki o upoważnieniu p. prorektora i dyrektora do pertraktacji z Zarządem Miejskim o przyznanie terenów Ogrodu Zoologicznego uniwersytetowi pod nowy budynek Biblioteki Uniwersyteckiej w zamian za dotychczasowy gmach przy ul. Ratajczaka. Kapitalny remont gmachu, który się rozpoczął, prowadzony był aż do 17 listopada 1945 roku, kiedy go przerwano z powodu braku dalszych funduszy. Najważniejszymi osiągnięciami były: rekonstrukcja i pokrycie dachu, naprawa wyrw spowodowanych przez pociski artyleryjskie we frontowej ścianie budynku, oszklenie świetlika nad główną klatką schodową i częściowe oszklenie okna. Jeszcze przed 1939 rokiem dotychczasowy gmach wymagał rozbudowy, niestety z powodu braku środków finansowych nie zdołano podjąć tej inwestycji. Sytuacja zmieniła się w 1945 roku - w sąsiedztwie gmachu Biblioteki pozostały parcele po wypalonych budynkach. Przygotowano szkicowe plany rozbudowy Biblioteki na sąsiednich parcelach (ul. Ratajczaka nr 2 i nr 3, plac Wolności nr 9). Autorami szkiców rozbudowy byli inż. Leonard Tomaszewski i inż. Stanisław Podgórski z Pracowni Urbanistycznej. Przeszkodą w realizacji rozbudowy stał się brak 
funduszy na zakupienie parceli sąsiadujących z obecnym budynkiem. W lutym 1946 roku w gmachu Biblioteki Uniwersyteckiej uruchomiono centralne ogrzewanie, tym samym dyrektor Biblioteki okólnikiem nr 4 z 18 lutego 1946 roku wprowadził nowe godziny urzędowania: codziennie od 8 do 14. Dla osób pracujących w budynku bibliotecznym, jak też w zewnętrznych placówkach: Oddziale Odbudowy Biblioteki TPN przy ul. Mielżyńskiego 26/27, Referacie Segregacji w Bibliotece Publicznej przy ul. Św. Marcin 35, Referacie Segregacji przy ul. Stolarskiej 7.

Celem stwierdzenia braków w księgozbiorze Biblioteki Uniwersyteckiej w Poznaniu powstałych podczas wojny 1939-1945 prof. Birkenmajer zarządził skontrum generalne księgozbioru Biblioteki. Rozpoczęło się ono 16 maja 1946 roku. Odbywało się codziennie w godzinach od 8 do 10 pod kierunkiem dra Jana Baumgarta, kierownika Oddziału Konserwacji Zbiorów. Prace związane ze skontrum wykonywać mieli uczestnicy kursu bibliotekarskiego. Normalizacja życia Biblioteki przyspieszyła wiosną 1946 roku. 16 maja 1946 roku udostępniono dla publiczności Czytelnię Ogólna, Czytelnię Profesorską i Wypożyczalnię także w godzinach popołudniowych (16-20). Równocześnie zainicjowano i uregulowano działalność wewnętrznych placówek pracy bibliotecznej: Biura Przybytków, Biur Katalogowania, Referatu Oprawy Książek. Biblioteka Uniwersytecka, pierwsza w Polsce powojennej, uruchomiła wypożyczalnię międzybiblioteczną ${ }^{21}$.

Zakres działalności Biblioteki Uniwersyteckiej obejmował również Bibliotekę Towarzystwa Przyjaciół Nauk, administracyjnie i personalnie złączoną z Biblioteką Uniwersytecką w Poznaniu. Biblioteka PTPN została przez okupanta w 1940 roku zlikwidowana, ale ponad połowa jej zasobów książkowych ocalała. Książki znalazły się w składnicach poniemieckich oraz w skrzyniach ewakuowanych do Smogulca. Udało się niemal całość przewieźć do gmachu towarzystwa.

Prof. Birkenmajer planował powrót do Biblioteki Jagiellońskiej w Krakowie. Zachowało się pismo z 3 marca 1947 roku do Rektoratu Uniwersytetu Jagiellońskiego w Krakowie, w którym znajduje się informacja o złożeniu wniosku do Ministerstwa Oświaty o mianowanie dra Eustachego Gaberlego kustoszem Biblioteki Uniwersyteckiej w Poznaniu. Rektorat UJ prosił o przyspieszenie tej sprawy:

zarazem usilnie proszę Rektorat U.J. o potraktowanie tej sprawy jako bardzo pilnej, a to z tego względu, że najściślej łączy się ona z wnioskiem złożonym

${ }^{21}$ Archiwum BU, teczka Sprawozdawczość i statystyka roczna 7 III 1945-31 XII 1949, sygn. 351, s. 29. 
przez Uniwersytet Jagielloński Ministerstwu Oświaty w sprawie ewent. mojego powrotu do Biblioteki Jagiellońskiej w charakterze zastępcy dyrektora tejże Biblioteki. Dr Gaberle zajmuje bowiem obecne mieszkanie służbowe w gmachu Biblioteki Jagiellońskiej, które w zasadzie było przygotowane dla mnie i mojej rodziny, jak długo zatem nie będzie mianowany kustoszem w Poznaniu, nie będzie mógł tego mieszkania opróżnić i w zamian zająć, jak to zostało w swoim czasie umówione, mojego obecnego mieszkania służbowego w gmachu tut. Biblioteki Uniwersyteckiej. Pozwolę sobie przypomnieć, że pierwotny projekt mojego przeniesienia się do Krakowa już na jesieni r. 1946 rozchwiał się jedynie z tego powodu, że w.w. mieszkanie w gmachu Biblioteki Jagiellońskiej nie zostało wykończone na dzień 1.X.1946 r. na skutek czego między J.M. Rektorem Uniwersytetu Jagiellońskiego a mną stanęła wówczas ustna umowa, odraczająca sprawę do 1.IV.1947 r. ${ }^{22}$.

W kronice Biblioteki Maria Michałowska pod datą 1 lipca 1947 roku tak odnotowała odejście dyrektora Biblioteki:

Dyr. Dr Birkenmajer opuścił placówkę Poznańska, aby objąć kierownictwo Biblioteki Jagiellońskiej. W Poznaniu z żalem żegnanemu dyrektorowi pracownicy B-ki urządzili w gmachu Biblioteki uroczystość urozmaiconą śpiewem i deklamacjami.

Z powyższego zapisu kronikarskiego wynika, że dyrektor Biblioteki cieszył się sympatią pracowników i żegnany był z żalem. W liście napisanym w Warszawie 1 lipca 1947 roku do dr Zofii Kaweckiej pełniącej obowiązki dyrektora Biblioteki Uniwersyteckiej postanowił ofiarować swój księgozbiór tejże instytucji:

Niech więc te książki, wierne i kochane towarzyszki moich lat młodzieńczych i męskich, pozostaną nadal w Bibliotece Uniwersyteckiej w Poznaniu, gdzie może będą pożyteczniejsze dla ogółu, niż u mnie. Niech pozatem stanowią pamiątkę po tym krótkim, ale jakże dla mnie miłym okresie, który spędziłem w Wielkopolsce ${ }^{23}$.

Lata kierowania Biblioteką Uniwersytecką w Poznaniu były niezwykle trudne. W roku 1939 Biblioteka Uniwersytecka miała ustabilizowaną pozycję w mieście i weryfikowane codzienną praktyką normy i zasady

${ }^{22}$ Archiwum BU, teczka Osobowe ogólne 1945-1955, sygn. 474, s. 350-351.

23 Archiwum BU, teczka Dary dla Biblioteki Uniwersyteckiej w Poznaniu 7 I 1946-19 XII 1947, sygn. 630, s. 327. 
funkcjonowania, których nie trzeba było modyfikować i które dyrektor Birkenmajer akceptował.

W roku 1945, gdy powrócił na swe stanowisko, wszystko się zmieniło: powojenny chaos, stosunkowo niewielkie, ale jednak zniszczenia, drastyczna zmiana realiów społeczno-politycznych. W trakcie swoich krótkich rządów prof. Birkenmajer wykazał się ogromną energia politycznym wyczuciem i pomysłowością. Bardzo szybko potrafił przywrócić normalne funkcjonowanie Biblioteki. Chociaż nie udało mu się sfinalizować biurokratycznych formalności związanych $\mathrm{z}$ budową nowego gmachu, to przecież rzucona przezeń idea bardzo szybko nabrała realnych kształtów. Jeszcze w roku 1947 - ale już po wyjeździe profesora w Okręgowym Urzędzie Likwidacyjnym sąsiadującą z gmachem Biblioteki Uniwersyteckiej działkę przydzielono Uniwersytetowi Poznańskiemu. Droga do rozbudowy Biblioteki została otwarta.

\title{
Bibliografia
}

Nowicki R., Działalność Aleksandra Birkenmajera na rzecz ochrony zbiorów bibliotecznych. Ziemie zachodniej i pótnocnej Polski w latach 1945-1947, Poznań 2006.

Głowacka-Helak M., Rewindykacja księgozbioru Biblioteki Uniwersyteckiej w Poznaniu oraz zabezpieczanie zbiorów porzuconych i opuszczonych w latach 1945-1946 na terenie Wielkopolski i Ziem Odzyskanych, „,Roczniki Biblioteczne” 1991, z. 1/2.

Materiały Archiwum Biblioteki Uniwersyteckiej w Poznaniu z lat 1937-1947.

\section{MAŁGORZATA GŁOWACKA-HELAK}

\section{Prof. Aleksander Birkenmajer as a director of the University Library in Poznań in the years 1939-1947}

\begin{abstract}
This article presents the pre-war director of the University Library in Poznań, Prof. Aleksander Birkenmajer, to commemorate this year's $50^{\text {th }}$ anniversary of Birkenmajer's death. Prof. Birkenmajer took the reins of the University Library in March 1939, shortly before the outbreak of WWII. During the occupation, Birkenmajer was released of his duties and did not see his co-workers for a number of years. He came back to the Library in March 1945 to re-establish and commence regular duties of the institution between 1945-1947. The present article is based on the archival materials currently kept in the Archives of the University Library in Poznań.
\end{abstract}

Key words: Aleksander Birkenmajer, University Library in Poznań. 